\title{
A note on partial replacement of maize with rice bran in the pig diet on meat and backfat fatty acids*
}

\author{
R.M.L. de Campos ${ }^{1}$, E. Hierro ${ }^{1}$, J.A. Ordóńez ${ }^{2}$, T.M. Bertol ${ }^{3}$ \\ and L. de la Hoz ${ }^{1,4}$ \\ ${ }^{1}$ Departamento de Nutrición, Bromatología y Tecnología de los Alimentos, \\ Facultad de Veterinaria, Universidad Complutense de Madrid \\ 28040 Madrid, Spain \\ ${ }^{2}$ Instituto de Ciencia y Tecnología de la Carne, Universidad Complutense de Madrid \\ Avda. Puerta de Hierro s/n, 28040 Madrid, Spain \\ ${ }^{3}$ Embrapa Suinos e Aves, RB 153. Km 110 \\ CEP: 89700-000 Concórdia-SC, Brazil
}

(Received 1 February 2006; revised version 16 June 2006; accepted 5 July 2006)

\begin{abstract}
The effect of partial substitution of maize with rice bran (maize/rice bran, 62/38, w/w) on feed intake per animal, weight gain per animal at growing-finishing period $(\mathrm{kg})$, feed conversion ratio, weight at slaughter $(\mathrm{kg})$ and fatty acid composition of pork leg and backfat has been studied. The use of diets with maize and rice bran $(\mathrm{M} / \mathrm{RB})$ increased $(\mathrm{P}<0.05)$ the feed conversion ratio to 3.17 while a value of 3.02 was obtained when maize diets $(\mathrm{M})$ were used. Weights at slaughter were 107.5 and $119.9 \mathrm{~kg}$ in animal feed with $\mathrm{M} / \mathrm{RB}$ and $\mathrm{M}$, respectively. The fatty acid composition of backfat and pork leg was modified by the use of rice bran. In general, tissues from animals fed with $\mathrm{M} / \mathrm{RB}$ diets showed higher concentrations $(\mathrm{P}<0.05)$ of $\mathrm{C} 18: 2 \mathrm{n}-6$, C18:3n-3 and polyunsaturated fatty acids (PUFA) (n-6 and n-3) than that found in M diet.
\end{abstract}

KEY WORDS: pig, pork leg, backfat, fatty acids, maize, rice bran

\section{INTRODUCTION}

Rice bran is a low price by-product of rice which use allows reducing the final cost of pig rations. Research work published so far with this by-product shows that it is possible to use about $40 \%$ of defatted rice bran in swine feeds without affecting negatively both animal performance and carcass quality (Borin et al., 1988).

\footnotetext{
* R.M.L. de Campos was supported by a Predoctoral Grant from the Brazilian Government (CAPES)

${ }^{4}$ Corresponding author: e-mail: delahoz@vet.ucm.es
} 
Rice bran contains about $87 \%$ dry matter and, \%: crude protein $11-15$, lipids 15-20 and ash 6.5-10 (Juliano and Bechtel, 1994; Rostagno et al., 2000). Rice bran fat is characterized by a fatty acid composition of, \%: oleic 34-37, linoleic 36-42, palmitic 21-23, stearic 1.7 and linolenic 1.2 (Miyazawa et al., 1978; Juliano, 1994). It also contains proteins with a good amino acids balance for monogastric animals (EMBRAPA, 1991).

It has been widely described that fatty acid composition of pork muscle and adipose tissue lipids is mainly influenced by fat diet (Wiseman and Agunbiade, 1998; Kouba and Mourot, 1999; Hoz et al., 2003). For this reason it could be possible that the dietary inclusion of rice bran could modify the fatty acid composition of pork.

The objective of this work was to evaluate the effect of partial replacement of maize with rice bran in pig diets on some growth characteristics and on fatty acid composition of pork leg and backfat at the growing-finishing period.

\section{MATERIAL AND METHODS}

\section{Experimental design}

Twenty castrated crossed male pigs (MS 60 male based on Duroc, Large White and Pietrain $\times$ female F1 based on Large White and Landrace) (Fávero, 2000 ) with approximately $25 \mathrm{~kg} \mathrm{BW}$ were randomly distributed and located in individual cages and fed a conventional pig diet until they weighed around $40 \mathrm{~kg}$. Ten pigs were randomly assigned to each experimental diet. All pigs were fed ad libitum for 80 days and then weighed. Feed intake of each group of animals and animal weighed before slaughter were recorded.

Ingredients, chemical composition and fatty acids of experimental diets are shown in Table 1. Determination of feed composition was carried out according to AOAC (1995).

\section{Slaughter, sample collection and chemical analysis}

Animals were stunned, slaughtered and exsanguinated at a local slaughterhouse at Concordia, Santa Catarina State (Brazil). At $24 \mathrm{~h}$ post-mortem, pork from the whole forelegs of the left side of the carcass and the backfat were removed, immediately vacuum packed in low-oxygen permeable film and, kept at $-22^{\circ} \mathrm{C}$ until analysis. Protein (Kjeldhal nitrogen), moisture (oven air-drying method) and ash (muffle furnace) were analysed following AOAC (1995) procedures. Fatty acid analysis was carried out in duplicate within three weeks after slaughter. 
Table 1. Ingredients, chemical composition and calculated metabolizable energy of diets

\begin{tabular}{|c|c|c|}
\hline \multirow{2}{*}{ Item } & \multicolumn{2}{|c|}{ Diets } \\
\hline & maize/rice bran & maize \\
\hline \multicolumn{3}{|l|}{ Ingredients, $\mathrm{g} \mathrm{kg}^{-1}$ of diet } \\
\hline maize & 496 & 782 \\
\hline soyabean meal & 172 & 188 \\
\hline rice bran & 300 & - \\
\hline sodium chloride & 3 & 3 \\
\hline dicalcium phosphate & 2 & 8 \\
\hline lysine supplement & 1.6 & 1.6 \\
\hline vitamin and mineral premix ${ }^{1}$ & 2 & 2 \\
\hline anti parasite & 0.1 & 0.1 \\
\hline methionine & - & 0.3 \\
\hline threonine & 0.4 & 0.3 \\
\hline choline chloride & 0.4 & 0.4 \\
\hline Kaolin $\left(\mathrm{Al}_{2} \mathrm{O}_{7} \mathrm{Si}_{2} \cdot 2 \mathrm{H}_{2} \mathrm{O}\right)$ & 8 & 3 \\
\hline limestone $\left(\mathrm{CaCO}_{3}\right)$ & 11.6 & 7.8 \\
\hline adsorbent $\left(\mathrm{SiO}_{2}\right)$ & 3 & 3 \\
\hline zinc bacitracin & 0.2 & 0.2 \\
\hline Calculated energy, $\mathrm{MJ} \mathrm{kg}^{-1}$ & 13.5 & 13.5 \\
\hline \multicolumn{3}{|l|}{ Proximate analysis } \\
\hline dry matter, $\mathrm{DM} \mathrm{g} \mathrm{kg}{ }^{-1}$ feed & 887.5 & 876.4 \\
\hline crude protein, $\mathrm{g} \mathrm{kg}^{-1} \mathrm{WM}^{2}$ & 143.9 & 130.7 \\
\hline crude fat, $\mathrm{g} \mathrm{kg}^{-1} \mathrm{WM}$ & 57.0 & 29.9 \\
\hline crude fibre, $\mathrm{g} \mathrm{kg}^{-1} \mathrm{WM}$ & 65.2 & 22.9 \\
\hline crude ash, $\mathrm{g} \mathrm{kg}^{-1} \mathrm{WM}$ & 85.3 & 43.8 \\
\hline \multicolumn{3}{|l|}{ Fatty acid composition, $\mathrm{g} \mathrm{kg}^{-1} \mathrm{WM}$} \\
\hline $\mathrm{C} 14: 0$ & 0.030 & 0.012 \\
\hline $\mathrm{C} 16: 0$ & 3.155 & 1.693 \\
\hline $\mathrm{C} 18: 0$ & 0.435 & 0.347 \\
\hline C18:1n-9 & 7.790 & 3.914 \\
\hline $\mathrm{C} 18: 2 n-6$ & 8.745 & 5.614 \\
\hline $\mathrm{C} 18: 3 n-3$ & 0.518 & 0.198 \\
\hline$C 22: 6 n-3$ & 0.546 & 0.258 \\
\hline $\mathrm{SFA}^{3}$ & 3.621 & 2.060 \\
\hline MUFA $^{3}$ & 7.812 & 3.914 \\
\hline PUFA $^{3}$ & 9.810 & 6.070 \\
\hline total fatty acids & 21.221 & 12.036 \\
\hline
\end{tabular}

${ }^{1}$ vitamin and mineral premix provided per kg of diet in: IU: vit. A, 8000, vit. $\mathrm{D}_{3}, 2000$, vit. E, $10, \mathrm{mg}$ : menadione, 0.7 , vit. $\mathrm{B}_{1}, 0.6$, vit. $\mathrm{B}_{2}, 3.0$, niacin, 15 , pantothenic acid, 7 , vit. $\mathrm{B}_{6}, 1$, choline, $100, \mathrm{Fe}$, $60, \mathrm{Cu}, 7, \mathrm{Zn}, 45, \mathrm{Mn}, 5.0$, Se, $0.15, \mathrm{I}, 0.2, \mu \mathrm{g}:$ vit. $\mathrm{B}_{12}, 12$

${ }^{2} \mathrm{WM}$ - wet matter

${ }^{3}$ SFA - saturated fatty acids; MUFA - monounsaturated fatty acids; PUFA - polyunsaturated fatty acids 
For lipid analysis, the method of Hanson and Olley (1963) (lipid extraction), Hartman and Lago (1973) (methylation) and Firestone (1998) (analysis of fatty acid methyl esters) were used. Fatty acids were analysed using $0.5 \mu 1$ of sample in a Konik mod. HRGC 4000 gas chromatograph (Barcelona, Spain) equipped with a flame ionization detector and a capillary column CP Sil 88 Tailor Made FAME (Chrompak). The chromatographic conditions were as follows: the initial column temperature was $180^{\circ} \mathrm{C}$, which was kept for $2 \mathrm{~min}$, then raised to 225 at $3.0^{\circ} \mathrm{C} / \mathrm{min}$ and finally held for $15 \mathrm{~min}$; injector and detector temperature was $270^{\circ} \mathrm{C}$. Helium was used as carrier gas, at a flow rate of $2 \mathrm{ml} / \mathrm{min}$. Fatty acid methyl esters were identified by comparison with commercial standards analysed in the same conditions and quantified as percentage of total methyl esters.

\section{Statistical analysis}

The statistical analysis was performed using the multiple correspondence analysis, and the t-test from the Statistical Analysis System (SAS/1999-2001).

\section{RESULTS AND DISCUSSION}

Feed intake, weight gain per animal, feed conversion and weight at slaughter of animals fed with diets containing maize and rice bran $(\mathrm{M} / \mathrm{RB})$ or maize $(\mathrm{M})$ are shown in Table 2 . The use of rice brain reduced $(\mathrm{P}<0.05)$ the feed intake per animal

Table 2. Feed intake per animal $(\mathrm{kg})$, weight gain per animal $(\mathrm{kg})$, feed conversion ratio at growingfinishing period (80 days) and weight at slaughter $(\mathrm{kg})$ of animals fed diets containing maize and rice bran $(62 / 38, \mathrm{w} / \mathrm{w})$ or maize

\begin{tabular}{lccc}
\hline Indices & Maize/rice bran & Maize \\
\hline Feed intake per animal, kg & $214.45 \pm 9.17^{\mathrm{b}}$ & $236.19 \pm 11.28^{\mathrm{a}}$ \\
Weight gain per animal at growing-finishing period, $\mathrm{kg}$ & $67.7 \pm 2.03^{\mathrm{b}}$ & $78.2 \pm 2.47^{\mathrm{a}}$ \\
Feed conversion ratio & $3.17 \pm 0.09^{\mathrm{a}}$ & $3.02 \pm 0.09^{\mathrm{b}}$ \\
Weight at slaughter, kg & $107.5 \pm 3.20^{\mathrm{b}}$ & $119.9 \pm 3.47^{\mathrm{a}}$ \\
\hline
\end{tabular}

mean values \pm SD of 10 individual animals

a,b values with different letters are significantly different $(\mathrm{P}<0.05)$

(kg) from $236.2(\mathrm{M})$ to $214.4(\mathrm{M} / \mathrm{RB})$, the weight gain per animal at growingfinishing period $(\mathrm{kg})$ from $78.2(\mathrm{M})$ to $67.7(\mathrm{M} / \mathrm{RB})$ and the weight at slaughter from $119.9(\mathrm{M})$ to $107.5(\mathrm{M} / \mathrm{RB})$. All these reductions gave raise to a slightly increase $(\mathrm{P}<0.05)$ of the feed conversion ratio (3.17 vs 3.02) in the $\mathrm{M} / \mathrm{RB}$ diet which is in agreement with previous results from Campos (2002). This fact is probably due to a lower digestibility coefficient of rice bran when compare to maize (Rostagno et 
al., 2000) for protein ( 74.44 vs 81.5$)$, fat ( 80 vs 90 ), crude fibre (39.72 vs 41.42 ) and digestible organic matter (58.1 vs 76.4). In conclusion, animals fed on M/RB diet had lower feed intake, lower intake of total dry matter, higher intake of crude fat and similar crude protein ingestion.

No effect of dietary treatment was observed in $\mathrm{pH}$ at $24 \mathrm{~h}$, water, protein, and ash content (g/100 g wet matter) in pork leg and backfat (Table 3). Only a higher amount of fat $(\mathrm{P}<0.05)$ was found in backfat of animals fed with $\mathrm{M} / \mathrm{RB}$ diet while no differences for fat $(\mathrm{P}>0.05)$ were found in pork leg (Table 3$)$.

Table 3. Chemical composition ( $\mathrm{g} / 100 \mathrm{~g}$ wet matter), $\mathrm{pH}$ and fatty acids ( $\%$ of total methyl esters) of pork forelegs and backfat of animals fed diets containing maize and rice bran $(62 / 38, \mathrm{w} / \mathrm{w})$ or maize

\begin{tabular}{|c|c|c|c|c|}
\hline \multirow{2}{*}{ Item } & \multicolumn{2}{|c|}{ Foreleg } & \multicolumn{2}{|c|}{ Backfat } \\
\hline & maize/rice bran & maize & maize/rice bran & maize \\
\hline Water & $75.07 \pm 0.60$ & $75.59 \pm 0.79$ & $11.46 \pm 0.07^{b}$ & $14.16 \pm 0.05^{\mathrm{a}}$ \\
\hline Protein & $21.02 \pm 0.06$ & $20.58 \pm 0.11$ & $1.89 \pm 0.06$ & $1.76 \pm 0.04$ \\
\hline Fat & $2.42 \pm 0.30$ & $2.13 \pm 0.31$ & $85.65 \pm 0.44^{\mathrm{a}}$ & $82.60 \pm 0.83^{\mathrm{b}}$ \\
\hline Ash & $1.67 \pm 0.12$ & $1.74 \pm 0.12$ & $0.55 \pm 0.06$ & $0.48 \pm 0.04$ \\
\hline $\mathrm{pH}_{24}$ & $5.78 \pm 0.02$ & $5.74 \pm 0.03$ & $5.68 \pm 0.05$ & $5.64 \pm 0.07$ \\
\hline \multicolumn{5}{|l|}{ Fatty acid } \\
\hline C10:0 & $0.08 \pm 0.03$ & $0.06 \pm 0.02$ & $0.03 \pm 0.001$ & $0.04 \pm 0.01$ \\
\hline $\mathrm{C} 12: 0$ & $0.06 \pm 0.02$ & $0.06 \pm 0.01$ & $0.04 \pm 0.001$ & $0.04 \pm 0.02$ \\
\hline C14:0 & $1.01 \pm 0.24$ & $1.06 \pm 0.10$ & $0.76 \pm 0.01^{\beta}$ & $1.01 \pm 0.05^{\alpha}$ \\
\hline $\mathrm{C} 16: 0$ & $20.34 \pm 2.20$ & $21.45 \pm 1.79$ & $18.88 \pm 0.09^{\beta}$ & $22.98 \pm 1.24^{\alpha}$ \\
\hline $\mathrm{C} 16: 1 \mathrm{n}-7$ & $2.03 \pm 0.69$ & $2.10 \pm 0.28$ & $1.19 \pm 0.12$ & $1.12 \pm 0.26$ \\
\hline $\mathrm{C} 17: 0$ & $0.17 \pm 0.05$ & $0.20 \pm 1.79$ & $0.22 \pm 0.02^{\beta}$ & $0.32 \pm 0.05^{\alpha}$ \\
\hline C18:0 & $9.17 \pm 0.48$ & $11.21 \pm 2.07$ & $9.58 \pm 0.55$ & $12.74 \pm 1.98$ \\
\hline C18:1n-9 & $40.10 \pm 1.36$ & $43.77 \pm 3.43$ & $40.76 \pm 0.93$ & $44.41 \pm 2.31$ \\
\hline$C 18: 2 n-6$ & $19.99 \pm 2.01^{\mathrm{a}}$ & $14.83 \pm 2.12^{\mathrm{b}}$ & $22.07 \pm 2.32^{\alpha}$ & $13.73 \pm 0.48^{\beta}$ \\
\hline $\mathrm{C} 18: 3 n-3$ & $1.23 \pm 0.11^{\mathrm{a}}$ & $0.84 \pm 0.15^{\mathrm{b}}$ & $1.34 \pm 0.13^{\alpha}$ & $0.60 \pm 0.07^{\beta}$ \\
\hline C20:1n-9 & $0.62 \pm 0.22$ & $0.88 \pm 0.23$ & $0.88 \pm 0.04$ & $0.94 \pm 0.02$ \\
\hline $\mathrm{C} 22: 0$ & $0.79 \pm 0.28$ & $0.62 \pm 0.22$ & $0.52 \pm 0.10^{\alpha}$ & $0.32 \pm 0.01^{\beta}$ \\
\hline$C 22: 6 n-3$ & $0.22 \pm 0.07$ & $0.15 \pm 0.07$ & - & - \\
\hline $\mathrm{SFA}^{1}$ & $31.62 \pm 1.69$ & $34.66 \pm 3.63$ & $30.03 \pm 0.48^{\beta}$ & $37.45 \pm 1.38^{\alpha}$ \\
\hline MUFA $^{2}$ & $42.75 \pm 1.53$ & $46.75 \pm 3.78$ & $42.83 \pm 1.02$ & $46.47 \pm 2.41$ \\
\hline PUFA $^{3}$ & $21.44 \pm 2.07^{\mathrm{a}}$ & $15.82 \pm 2.19^{b}$ & $23.41 \pm 2.31^{\alpha}$ & $14.41 \pm 0.41^{\beta}$ \\
\hline PUFAn-6 & $19.99 \pm 2.01^{\mathrm{a}}$ & $14.83 \pm 2.11^{\mathrm{b}}$ & $22.07 \pm 2.32^{\alpha}$ & $13.73 \pm 0.48^{\beta}$ \\
\hline PUFAn-3 & $1.45 \pm 0.06^{\mathrm{a}}$ & $0.99 \pm 0.09^{b}$ & $1.34 \pm 0.13^{\alpha}$ & $0.68 \pm 0.07^{\beta}$ \\
\hline$n-6 / n-3$ ratio & $13.79 \pm 0.84$ & $15.00 \pm 1.55$ & $16.47 \pm 1.69$ & $20.19 \pm 1.83$ \\
\hline
\end{tabular}

${ }^{1}$ SFA - saturated fatty acids; ${ }^{2}$ MUFA - monounsaturated fatty acids; ${ }^{3}$ PUFA - polyunsaturated fatty acids; ${ }^{\text {a,b }}$ values in row with different letters are statistically different $(\mathrm{P}<0.05){ }^{\alpha, \beta}$ values in row with different letters are statistically different $(\mathrm{P}<0.05)$ 
The effect of $\mathrm{M} / \mathrm{RB}$ and $\mathrm{M}$ diet on fatty acid composition of pork legs and backfat are shown in Table 3. The partial replacement of maize with rice bran (diet M/RB) increased the content of total polyunsaturated fatty acids (PUFA) in both pork leg and backfat. The concentration of C18:2n-6, the main n- 6 fatty acid, and therefore, the total $n-6$ fatty acids were significantly higher $(P<0.05)$ in both tissues of animals fed with $\mathrm{M} / \mathrm{RB}$ diet. Also, the use of the $\mathrm{M} / \mathrm{RB}$ diet produced an increase $(\mathrm{P}<0.05)$ in the C18:3n-3 and total n-3 fatty acid concentration. The fatty acid composition of pork backfat (Table 3 ) also showed significant differences $(\mathrm{P}<0.05)$ for the saturated fatty acids, C14:0, C16:0, C17:0 and C22:0. In general, the results concerning n-3 and $n-6$ fatty acids were seen as expected because the $M / R B$ diet (Table 1 ) is richer in C18:2n-6 and C18:3n-3 and, as we previously stated, fatty acid composition in backfat and muscle reflects fatty acid composition in the diet.

The higher variation on the fatty acid composition of backfat is in agreement with the results of Kouba and Mourot (1999), Warnants et al. (1999) and Enser et al. (2000) who stated that diets have a weaker influence on muscular fat than on adipose tissue.

The n-6/n-3 ratio in pork foreleg and backfat was not modified by dietary inclusion of rice bran. In both diets, this ratio was higher than the value recommended by the British Nutrition Foundation (1992) in the human diet. Therefore, it should be made an effort to decrease the $n-6 / n-3$ ratio to values closer to the nutritional recommendations in order to improve the nutritional quality of this meat.

\section{CONCLUSIONS}

The results for weight gain, feed intake and conversion and fatty acid composition of pork foreleg and backfat prove that maize could be partially substituted by rice bran in pig diet at growing-finishing period, although a slightly higher feed conversion ratio was observed when diets with rice bran were used.

\section{REFERENCES}

AOAC, 1995. Official Methods of Analysis, Association of Official Analytical Chemists. $16^{\text {th }}$ Edition. Washington, DC

Borin J.R.H., Gai J.N., Silveira J.C.G.L., 1988. Effect of the addition of different levels of defatted rice bran in pig diet in growing and finishing period (in Portugese). Rev. Soc. Bras. Zootec. 17, 553-563

British Nutrition Foundation, 1992. Unsaturated Fatty Acids: Nutritional and Physiological Significance. The Report of British Nutrition Foundation's Task Force. Chapman and Hall, London

Campos R.M.L., 2002. Influence of feeding on pig carcass and hind leg quality for Italian type salami manufacture (in Portugese). Master dissertation, Department of Food Technology and Science, University Federal de Santa Maria (Brazil) 
EMBRAPA, Empresa Brasileira de Pesquisa Agropecuária, 1991. Tables of Chemical Composition and Energy Values of Feedstuffs for Swine and Poultry (in Portugese). $3^{\text {rd }}$ Edition. Concórdia: EMBRAPA, CNPSA, pp. 97

Enser M., Richardson R.I., Wood J.D., Gill B.P., Sheard P.R., 2000. Feeding linseed to increase the n-3 PUFA of pork: fatty acid composition of muscle, adipose tissue, liver and sausages. Meat Sci. 55, 201-212

Fávero J.A., 2000. Modifications of performance and carcass characteristics of the synthetic line Embrapa MS 58 (in Portugese). In: Congreso Mercosur de Producción Porcina, n. 01, Buenos Aires (Argentina), p. G3

Firestone D., 1998. Official Methods and Recommended Practices of the American Oil Chemists Society, AOCS. Vol I.-II. $5^{\text {th }}$ Edition. Champaign

Hanson S.W.F., Olley J., 1963. Application of the Bligh and Dyer method of lipid extraction to tissue homogenates. Biochem. J. 89, 101P-102P

Hartman L., Lago R.C.A., 1973. Rapid preparation of fatty acid methyl esters from lipids. Lab. Pract. 22, 475-476

Hoz L., López-Bote C.J., Cambero M.I., D’Arrigo M., Pin C., Santos C., Ordóńez J.A., 2003. Effect of dietary linseed oil and $\alpha$-tocopherol on pork tenderloin (Psoas major) muscle. Meat Sci. 65, 1039-1044

Juliano B.O., 1994. Polysaccharides, proteins and lipids of rice. In: Rice Chemistry and Technology. The American Association of Cereal Chemists, Inc. St. Paul, Minnesota, pp. 59-174

Juliano B.O., Bechtel D.B., 1994. The rice grain and its gross composition. In: Rice Chemistry and Technology. The American Association of Cereal Chemists, Inc. St. Paul, Minnesota, pp. 17-57

Kouba M., Mourot J., 1999. Effect of feeding linoleic acid diets on lipogenic enzyme activities and on the composition of the lipid fraction of the fat and lean tissues in the pig. Meat Sci. 52, 3945

Miyazawa T., Tazawa H., Fujino Y., 1978. Molecular species of triglyceride in rice bran. Cereal Chem. 55, 138-145

Rostagno H.S., Albino L.F.T., Donzele J.L., Ferreira A.S., Oliveira R.F., Lopes D.C., 2000. In: H.S. Rostagno (Editor). Brazilian Tables for Poultry and Swine: Feedstuffs Composition and Nutrient Requirements (in Portugese). Vicosa UFV, pp. 141

SAS Institute Inc., 1999-2001. System for Microsoft Windows, Release 8.2, Cary, NC

Warnants N., Van Oeckel M.J., Boucquc̀ C.V., 1999. Incorporation of dietary polyunsaturated fatty acids in pork tissues and its implication for the quality of the end products. Meat Sci. 44, 125 144

Wiseman J., Agunbiade J.A., 1998. The influence of changes in dietary fat and oils on fatty acid profiles of carcass fat in finishing pigs. Livest. Prod. Sci. 54, 217-227 